\title{
Determination of Amino Acids in Plasma Samples of Preeclampsia Patients by Liquid Chromatography Coupled to High-Resolution Mass Spectrometry
}

\author{
Eliane do Nascimento, ${ }^{a}$ Helvécio C. Menezes, ${ }^{a}$ Rodrigo R. Resende, ${ }^{b}$ \\ Vânia A. M. Goulart ${ }^{b}$ and Zenilda L. Cardeal ${ }^{\circledR} * a$ \\ ${ }^{a}$ Departamento de Química, Universidade Federal de Minas Gerais, \\ Av. Antônio Carlos 6627, 31270-901 Belo Horizonte-MG, Brazil \\ ${ }^{b}$ Departamento de Bioquímica e Imunologia, Instituto de Ciências Biológicas, \\ Universidade Federal de Minas Gerais, Av. Antônio Carlos, 6627, 31270-901 Belo Horizonte-MG, Brazil
}

\begin{abstract}
This work presents the application of a simple and sensitive method developed for the simultaneous analysis of the levels of twenty two underivatizated free L-amino acids in plasma samples of preeclampsia patients by high performance liquid chromatography coupled to high-resolution mass spectrometer (LC-HRMS) using hydrophilic interaction liquid chromatography (HILIC) silica column. The linearity was evaluated in the range of 0.009 to $8.018 \mu \mathrm{mol} \mathrm{L} \mathrm{L}^{-1}$ showing coefficients of determination $\left(\mathrm{R}^{2}\right)$ in the range of 0.999 to $0.911(p<0.05)$. The intra- and inter-day precisions were above of 9.84 and 15.31, respectively. The limits of detection (LOD) and quantification (LOQ) were in the range of 0.003 to $0.683 \mu \mathrm{mol} \mathrm{L}^{-1}$ and 0.009 to $2.276 \mu \mathrm{mol} \mathrm{L}-1$, respectively. The results of the investigation of free $\mathrm{L}$-amino acids showed that the levels of GABA, Arg, Ser, Leu, Ile, Met, Val, Ala, Gly, Bet, His and Lys in plasma of patients with preeclampsia were significantly different from healthy patients.
\end{abstract}

Keywords: L-amino acids, biomarkers, preeclampsia, LC-HRMS-ESI-IT-TOF

\section{Introduction}

The direct analyses of free amino acids (AA) is very important in metabolomics studies and have been an important implement of search for understanding, diagnostic and treatment of various diseases. ${ }^{1-7}$ Amino acids are important metabolites for various metabolic pathways, contributing for several biochemical reactions that involves a wide metabolic network within living cell. Therefore, amino acids play an important role in connecting the diverse metabolic pathways since changing the level of one amino acid in response to environmental transformation and/or genetic variation originates disruptions in the levels of several other amino acids. ${ }^{8}$ Various analytical methods were described in the literature for the determination of free amino acids in biological samples such as serum, ${ }^{9}$ plasma, ${ }^{1,10-14}$ sweat, ${ }^{15}$ saliva, ${ }^{5,16,17}$ tissue $^{18}$ or urine. ${ }^{7}$ Chromatography methods as LC-HRMS (liquid chromatography-high resolution mass spectrometry) and GC-MS (gas chromatography mass spectrometry) are more frequently used due to their high sensitivity and selectivity. ${ }^{16-20}$ GC-MS presents higher

*e-mail: zenilda@ufmg.br sensitivity but free amino acids should be derivatizated before analysis. ${ }^{19,20}$ On the other hand, LC-MS (liquid chromatography mass spectrometry) is suitable for amino acids analysis due to better compatibility and application to bioassays involving high polar compounds, greater simplicity in sample preparation procedure without derivatization steps and shorter analysis time. ${ }^{13}$ Besides this, LC-HRMS presents high selectivity and sensitivity, therefore high capacity to identify and detect coelutions not resolved by chromatography. Recently, Cocuron et al. ${ }^{21}$ proposed a high sensitivity method to analyze amino acids by LC-MS method, nevertheless the proposed method can analyze only 19AAs. The use of hydrophilic interaction liquid chromatography (HILIC) to amino acid analysis is growing up because it is efficient to separate very polar analytes quickly. ${ }^{22-24}$ This work presents the development of a simple and sensitive method for the analysis of twenty two underivatizated free L-amino acids using hydrophilic interaction through liquid chromatography coupled to a high-resolution ion trap and time-of-flight mass spectrometry (LC-HRMS-IT-TOF). This method was successfully applied to investigate the levels of free L-amino acids in plasma sample of humans' patients with preeclampsia. 


\section{Experimental}

\section{Chemicals and reagents}

Amino acids of high-purity ( $\geq 98 \%$ ), L-tryptophan (Trp), L-phenylalanine (Phe), L-tyrosine (Tyr), L-leucine (Leu), L-isoleucine (Ile), L-methionine (Met), L-valine (Val), L-glutamic acid (Glu), $\gamma$-aminobutyric acid (GABA), L-aspartic acid (Asp), L-alanine (Ala), L-threonine (Thr), L-serine (Ser), L-glycine (Gly), L-proline (Pro), L-sarcosine (Sar), L-asparagine (Asn), L-glutamine (Gln), L-betaine (Bet), L-arginine (Arg), L-histidine (His), L-lysine (Lys) were purchased from Sigma-Aldrich (St. Louis, MO, USA). Acetonitrile (HPLC grade) and formic acid $88 \%$ were purchased from J. T. Baker (Xalostoc, Edo do México, Mexico). Ultra-pure water was purified with a Purelab Classic from Elga (Woodridge, Illinois, USA). Other chemicals were of analytical grade.

\section{Solutions preparation}

Standard stock solutions of amino acids in water were prepared at $1161.4-13321.0 \mu \mathrm{mol} \mathrm{L}^{-1}$. The mixed standard solutions and working solutions were obtained by sequential dilutions using the mixture acetonitrile (ACN):water $(50: 50, v / v)$ or $\mathrm{ACN}$ :water $(90: 10, \mathrm{v} / \mathrm{v})$ with $0.1 \%$ of formic acid.

\section{Sample preparation}

Human plasma samples were provided by the Biomarker Laboratory of the Research Institute of the Santa Casa de Misericórdia of Belo Horizonte (Belo Horizonte-MG, Brazil). This study was approved by the Research Ethics Committees of the Santa Casa de Misericórdia of Belo Horizonte under No. 315034. Fourteen patients were recruited with preeclampsia and ten healthy pregnant women (control) who signed the informed consent form. The demographic data of the study group were: pregnant women with a mean age of $26.07 \pm 5.23$ years and $33.64 \pm 4.48$ weeks of gestation presenting systolic pressure of $143.40 \pm 12.14 \mathrm{mmHg}$ and diastolic pressure of $31.00 \pm 4.64 \mathrm{mmHg}$. And healthy patients with a mean age of $27.50 \pm 6.16$ years and $34.80 \pm 2.20$ weeks of gestation presenting systolic and diastolic blood pressure of $109.80 \pm 10.34$ and $69.80 \pm 6.70 \mathrm{mmHg}$, respectively. Venous blood samples from all patients were collected in tubes of the Vacuette system (Vacuette ${ }^{\circledR}$ do Brasil LTDA, São Paulo, SP, Brazil) containing the anticoagulant ethylenediaminetetraacetic acid (EDTA). The samples were centrifuged at $3000 \mathrm{rpm}$ for $15 \mathrm{~min}$ at room temperature. Blood plasma was collected and stored at $-80{ }^{\circ} \mathrm{C}$ until use. In the chemistry laboratory of Universidade Federal de Minas Gerais, Brazil, all plasma samples were prepared using methanol iced to precipitate proteins. $100 \mu \mathrm{L}$ of plasma sample was transferred to the vial and $900.0 \mu \mathrm{L}$ of methanol at $-10^{\circ} \mathrm{C}$ were added. The mixture was centrifuged at 10,000 rpm for $10 \mathrm{~min}$ at room temperature. $100 \mu \mathrm{L}$ of supernatant was transferred to Eppendorf tube for solvent evaporation at dryness under nitrogen. The solid was redissolved in $200.0 \mu \mathrm{L}$ of ACN:water (90:10, v/v) with $0.1 \%$ formic acid and analyzed by LC-HRMS.

Instrumental analysis

All analysis were performed on a high performance liquid chromatography (HPLC) Promidence 20AC equipped with a system controller CBM-20A, an autosampler SIL-30AC, a binary solvent system LC-20AD, and a column heater CTO-20AC from Shimadzu Corp. (Tokyo, Japan). Chromatographic separation was performed with a HILIC silica column $(2.1 \times 150 \mathrm{~mm}$, $3.0 \mu \mathrm{m}$ particle size) and an Atlantis HILIC silica precolumn $(2.1 \times 10 \mathrm{~mm} \times 3 \mu \mathrm{m})$, both from Waters Corp. (Milford, MA, USA). The conditions of chromatography were: sample injection volumes of $20.0 \mu \mathrm{L}$, column was maintained at $35.0{ }^{\circ} \mathrm{C}$, flow rate of mobile phase at $0.2 \mathrm{~mL} \mathrm{~min}^{-1}$. The mobile phase used was a binary system of $0.1 \%$ formic acid aqueous solution (A) and acetonitrile containing $0.1 \%$ formic acid (B). The gradient elution started with $15 \% \mathrm{~A}$, rinsing to $60 \% \mathrm{~A}$ in $13.0 \mathrm{~min}$, which was then held for $2.0 \mathrm{~min}$, then reduced to $15 \%$ in $15.5 \mathrm{~min}$, and held for $4.5 \mathrm{~min}$. The HRMS was an hybrid IT-TOF from Shimadzu Corp. (Tokyo, Japan) with mass accuracy $(<5 \mathrm{ppm})$ equipped with an electrospray ionization (ESI) source operating in positive mode under the conditions: $\mathrm{N}_{2}$ nebulizing gas flow of $1.5 \mathrm{~L} \mathrm{~min}^{-1}$; curved desorption line (CDL) interface temperature of $250{ }^{\circ} \mathrm{C}$; detector voltage $2.00 \mathrm{kV}$; drying gas pressure of $114 \mathrm{kPa}$; octopole ion accumulation time of $100 \mathrm{~ms}$; detection of the protonated ions $[\mathrm{M}+\mathrm{H}]^{+}$was carried out in $\mathrm{m} / \mathrm{z}$ range of 60-250 with an resolution power over 10,000 .

\section{Method performance}

The limit of detection (LOD) and limit of quantification (LOQ) were calculated according to Eurachem Guide. ${ }^{25}$ Ten replicates of solutions without amino acids in conditions identical of working standard solutions were analyzed. The intra-day precision was studied analyzing on the same day three concentration levels (low, medium, and high) in 
replicates $(n=7)$ for each concentration level. The inter-day precision was performed analyzing on three different days three concentration levels in replicates $(n=7)$ for each concentration level.

\section{Statistical analysis}

Statistical analyses were performed by one-way analysis of variance (ANOVA) and Tukey test was achieved by Origin version $8.0 .{ }^{26}$ Values of $p<0.05$ were considered statistically significant in all statistical studies.

\section{Results and Discussion}

\section{Optimization of chromatographic and mass spectrometric conditions}

Figure 1 shows an overview of optimized method and Figure 2, the LC-HRMS chromatograms obtained for water solutions spiked at $5.0 \mu \mathrm{mol} \mathrm{L}-1$. Positive ionization mode increased the method sensitivity. The HILIC silica column increased separation efficiency of amino acids that are quite polar analytes. ${ }^{23,24}$ Furthermore, the gradual increase of the mobile phase polarity provides analytes protonation. Table 1 shows mass spectrometer data for the amino acids obtained by the optimized method.

\section{Figure of merits}

Table 2 shows the figure of merits of optimized method. The proximity of the experimental measurement to the true value (exact mass) of protoned amino acid ions shows error lower than $5 \mathrm{ppm}$. The calibration curves were

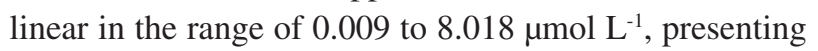
coefficients of determination $\left(\mathrm{R}^{2}\right)$ in the range of 0.999 to 0.985 for all amino acids except lysine (0.911), histidine (0.977) and arginine (0.978). The LODs and LOQs ranged from 0.003 to $0.683 \mu \mathrm{mol} \mathrm{L}{ }^{-1}$ and 0.009 to $2.276 \mu \mathrm{mol} \mathrm{L} \mathrm{L}^{-1}$, respectively. The relative standard deviation (\% RSD) for intra-day precision ranged from 4.2 to $16.2 \%$ and inter-day was from 7.0 to $19.1 \%$.

\section{Statistical analysis}

The optimized method was applied to analyze plasma samples of preeclampsia $(n=14)$ patients and healthy controls $(n=10)$ groups, which results are shown in Table 3. All mean concentrations (Figure 3) were above LOQs. ANOVA followed by Tukey test were applied to the discrimination of the levels of amino acids of plasma from preeclampsia and healthy controls. The results from this test indicated that the difference between means is significant ( $p$-value < 0.05) for GABA, Arg, Ser, Leu, Ile, Met, Val, Ala, Gly, Bet, His and Lys, suggesting these AAs as potential biomarkers. The differences in levels of twelve amino acids discriminated by Tukey test in two groups (preeclampsia and controls) can be visualized in the box plot (Figure 4).

\section{Preeclampsia analyses}

The method we developed for the simultaneous analysis of 22 underivatized amino acids in blood plasma using LC-HRMS was applied in analysis of amino acid levels in blood plasma samples from patients with preeclampsia. Preeclampsia, also known as hypertensive pregnancy disease, is a dangerous complication of pregnancy, characterized by high blood pressure and the presence of protein in the urine that appears after the $20^{\text {th }}$ week of gestation. Although metabolic studies have already been conducted using advanced technologies, ${ }^{27-34}$ the metabolic profile of patients with preeclampsia and biomarkers of the disease have not yet been elucidated for early identification of the disease and understanding of its pathogenesis. In this work a small contribution is made in metabolomics studies to identify possible biomarkers of preeclampsia. Through the statistical analysis of the results of the amino acid levels found in plasma samples from patients with preeclampsia, it was found that 12 of



Figure 1. Overview of optimized method of LC-HRMS. LC conditions: mobile phase A, $\mathrm{H}_{2} \mathrm{O}$ with $0.1 \%$ FA and B, ACN with $0.1 \%$ FA, flow rate was $0.2 \mathrm{~mL} \mathrm{~min}{ }^{-1}$ in HILIC silica column. MS conditions: nebulizing gas flow, $1.5 \mathrm{~L} \mathrm{~min}^{-1}$; CDL temperature, $250{ }^{\circ} \mathrm{C}$; heat block temperature, $250{ }^{\circ} \mathrm{C}$; detector voltage, $2.00 \mathrm{kV}$; drying gas pressure, $114.0 \mathrm{kPa}$. Positive-ion mode with detection of protonated ions in $\mathrm{m} / \mathrm{z}$, range of $60-250$. 

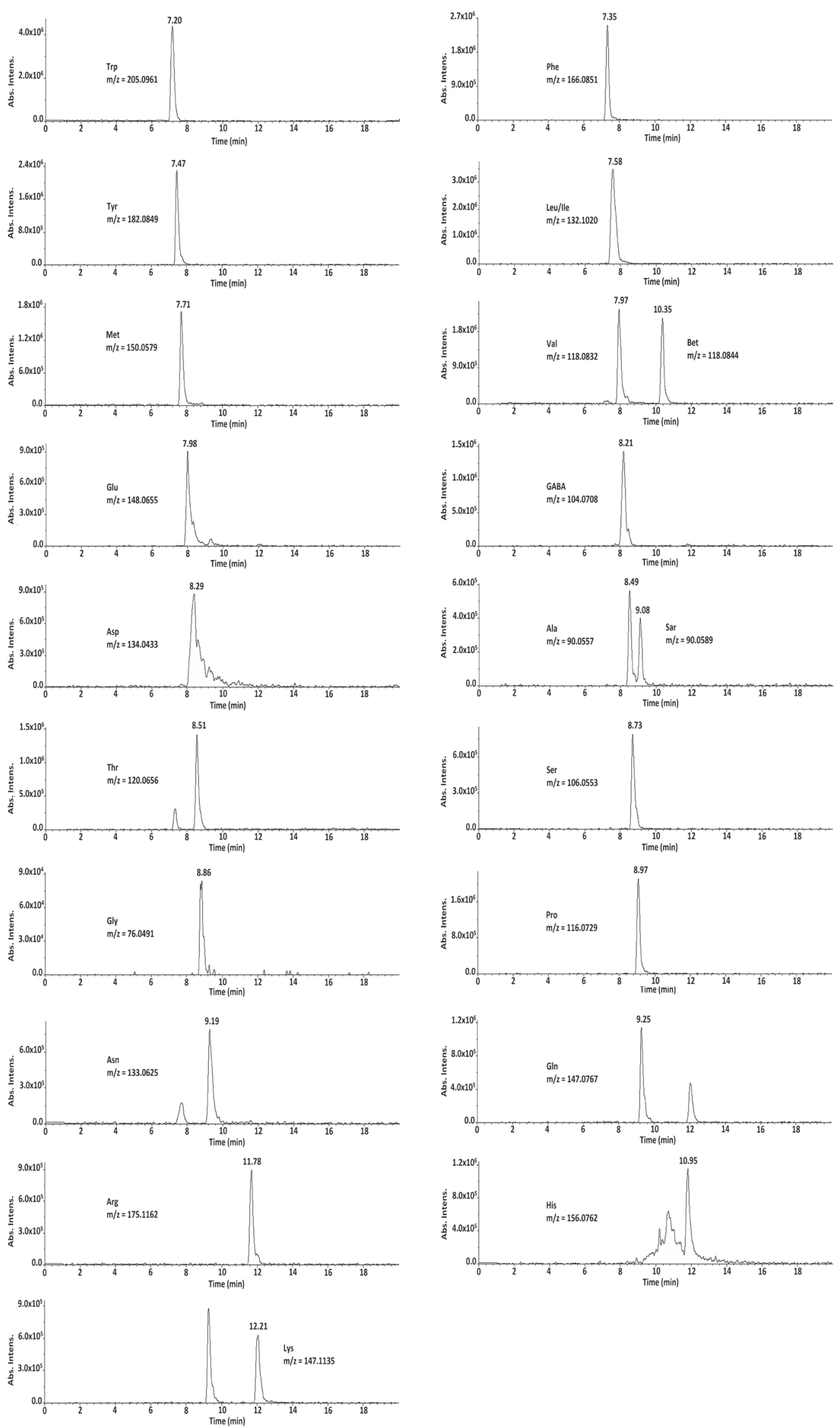

Figure 2. LC-HRMS chromatograms of underivatized L-amino acids aqueous solution spiked at $5.0 \mu \mathrm{mol} \mathrm{L}^{-1}$. 
Table 1. Mass spectrometer data for the amino acids

\begin{tabular}{|c|c|c|c|c|}
\hline Amino acid & Molecular formula & Theoretical $[\mathrm{M}+\mathrm{H}]^{+} \mathrm{m} / z$ & Experimental $[\mathrm{M}+\mathrm{H}]^{+} \mathrm{m} / z$ & $\mathrm{t}_{\mathrm{R}} / \min$ \\
\hline$\overline{\operatorname{Trp}}$ & $\mathrm{C}_{11} \mathrm{H}_{12} \mathrm{~N}_{2} \mathrm{O}_{2}$ & 205.0977 & 205.0961 & 7.20 \\
\hline Phe & $\mathrm{C}_{9} \mathrm{H}_{11} \mathrm{NO}_{2}$ & 166.0868 & 166.0851 & 7.35 \\
\hline Tyr & $\mathrm{C}_{9} \mathrm{H}_{11} \mathrm{NO}_{3}$ & 182.0817 & 182.0849 & 7.47 \\
\hline Leu & $\mathrm{C}_{6} \mathrm{H}_{13} \mathrm{NO}_{2}$ & 132.1025 & 132.1020 & 7.58 \\
\hline Ile & $\mathrm{C}_{6} \mathrm{H}_{13} \mathrm{NO}_{2}$ & 132.1025 & 132.1020 & 7.58 \\
\hline Met & $\mathrm{C}_{5} \mathrm{H}_{11} \mathrm{NO}_{2} \mathrm{~S}$ & 150.0589 & 150.0579 & 7.71 \\
\hline Val & $\mathrm{C}_{5} \mathrm{H}_{11} \mathrm{NO}_{2}$ & 118.0868 & 118.0832 & 7.97 \\
\hline Glu & $\mathrm{C}_{5} \mathrm{H}_{9} \mathrm{NO}_{4}$ & 148.0610 & 148.0655 & 7.98 \\
\hline GABA & $\mathrm{C}_{4} \mathrm{H}_{9} \mathrm{NO}_{2}$ & 104.0712 & 104.0708 & 8.21 \\
\hline Asp & $\mathrm{C}_{4} \mathrm{H}_{7} \mathrm{NO}_{4}$ & 134.0453 & 134.0433 & 8.29 \\
\hline Ala & $\mathrm{C}_{3} \mathrm{H}_{7} \mathrm{NO}_{2}$ & 90.0555 & 90.0557 & 8.49 \\
\hline Thr & $\mathrm{C}_{4} \mathrm{H}_{9} \mathrm{NO}_{3}$ & 120.0661 & 120.0656 & 8.51 \\
\hline Ser & $\mathrm{C}_{3} \mathrm{H}_{7} \mathrm{NO}_{3}$ & 106.0504 & 106.0553 & 8.73 \\
\hline Gly & $\mathrm{C}_{2} \mathrm{H}_{5} \mathrm{NO}_{2}$ & 76.0399 & 76.0491 & 8.86 \\
\hline Pro & $\mathrm{C}_{5} \mathrm{H}_{9} \mathrm{NO}_{2}$ & 116.0706 & 116.0729 & 8.97 \\
\hline Sar & $\mathrm{C}_{3} \mathrm{H}_{7} \mathrm{NO}_{2}$ & 90.0555 & 90.0589 & 9.08 \\
\hline Asn & $\mathrm{C}_{4} \mathrm{H}_{8} \mathrm{~N}_{2} \mathrm{O}_{3}$ & 133.0613 & 133.0625 & 9.19 \\
\hline Gln & $\mathrm{C}_{5} \mathrm{H}_{10} \mathrm{~N}_{2} \mathrm{O}_{3}$ & 147.0764 & 147.0767 & 9.25 \\
\hline Bet & $\mathrm{C}_{5} \mathrm{H}_{10} \mathrm{NO}_{2}$ & 118.0868 & 118.0844 & 10.35 \\
\hline Arg & $\mathrm{C}_{6} \mathrm{H}_{14} \mathrm{~N}_{4} \mathrm{O}_{2}$ & 175.1190 & 175.1162 & 11.78 \\
\hline His & $\mathrm{C}_{6} \mathrm{H}_{9} \mathrm{~N}_{3} \mathrm{O}_{2}$ & 156.0773 & 156.0762 & 10.95 \\
\hline$\underline{\text { Lys }}$ & $\mathrm{C}_{6} \mathrm{H}_{14} \mathrm{~N}_{2} \mathrm{O}_{2}$ & 147.1128 & 147.1135 & 12.21 \\
\hline
\end{tabular}

$\mathrm{t}_{\mathrm{R}}$ : retention time; Trp: L-tryptophan; Phe: L-phenylalanine; Tyr: L-tyrosine; Leu: L-leucine; Ile: L-isoleucine; Met: L-methionine; Val: L-valine; Glu: L-glutamic acid; GABA: $\gamma$-aminobutyric acid; Asp: L-aspartic acid; Ala: L-alanine; Thr: L-threonine; Ser: L-serine; Gly: L-glycine; Pro: L-proline; Sar: L-sarcosine; Asn: L-asparagine; Gln: L-glutamine; Bet: L-betaine; Arg: L-arginine; His: L-histidine; Lys: L-lysine.

Table 2. Figure of merits for the analysis of amino acids by LC-HRMS method

\begin{tabular}{|c|c|c|c|c|c|c|c|c|c|c|}
\hline \multirow[b]{2}{*}{ Amino acid } & \multirow{2}{*}{$\begin{array}{l}\text { Elemental } \\
\text { composition }\end{array}$} & \multirow{2}{*}{$\begin{array}{l}\text { Retention } \\
\text { time / min }\end{array}$} & \multirow{2}{*}{$\begin{array}{c}\text { Exact mass } \\
{[\mathrm{M}+\mathrm{H}]^{+} m / z}\end{array}$} & \multirow{2}{*}{$\begin{array}{c}\text { Measured mass } \\
{[\mathrm{M}+\mathrm{H}]^{+} m / z}\end{array}$} & \multirow{2}{*}{$\begin{array}{c}\text { Linear } \\
\text { range / } \\
\left(\mu \mathrm{mol} \mathrm{L}{ }^{-1}\right)\end{array}$} & \multirow{2}{*}{$\begin{array}{c}\text { LOD / } \\
\left(\mu \mathrm{mol} \mathrm{L}{ }^{-1}\right)\end{array}$} & \multirow{2}{*}{$\begin{array}{c}\text { LOQ / } \\
\left(\mu \mathrm{mol} \mathrm{L}{ }^{-1}\right)\end{array}$} & \multirow[b]{2}{*}{$\mathrm{R}^{2}$} & \multicolumn{2}{|c|}{ Precision / (\% RSD) } \\
\hline & & & & & & & & & $\begin{array}{c}\text { Intra-day } \\
(\mathrm{n}=21)\end{array}$ & $\begin{array}{c}\text { Inter-day } \\
(\mathrm{n}=21)\end{array}$ \\
\hline Trp & $\mathrm{C}_{11} \mathrm{H}_{12} \mathrm{~N}_{2} \mathrm{O}_{2}$ & 7.20 & 205.0977 & 205.0961 & $0.059-1.210$ & 0.018 & 0.059 & 0.9931 & 5.9 & 10.1 \\
\hline Phe & $\mathrm{C}_{9} \mathrm{H}_{11} \mathrm{NO}_{2}$ & 7.35 & 166.0868 & 166.0851 & $0.009-1.500$ & 0.003 & 0.009 & 0.9868 & 5.8 & 14.1 \\
\hline Tyr & $\mathrm{C}_{9} \mathrm{H}_{11} \mathrm{NO}_{3}$ & 7.47 & 182.0817 & 182.0849 & $0.021-1.451$ & 0.006 & 0.021 & 0.9904 & 6.1 & 9.5 \\
\hline Leu & $\mathrm{C}_{6} \mathrm{H}_{13} \mathrm{NO}_{2}$ & 7.58 & 132.1025 & 132.1020 & $0.036-3.781$ & 0.011 & 0.036 & 0.9697 & 4.2 & 13.8 \\
\hline Ile & $\mathrm{C}_{6} \mathrm{H}_{13} \mathrm{NO}_{2}$ & 7.58 & 132.1025 & 132.1020 & $0.036-3.781$ & 0.011 & 0.036 & 0.9697 & 4.2 & 13.8 \\
\hline Met & $\mathrm{C}_{5} \mathrm{H}_{11} \mathrm{NO}_{2} \mathrm{~S}$ & 7.71 & 150.0589 & 150.0579 & $0.067-1.696$ & 0.020 & 0.067 & 0.9897 & 8.1 & 14.3 \\
\hline Val & $\mathrm{C}_{5} \mathrm{H}_{11} \mathrm{NO}_{2}$ & 7.97 & 118.0868 & 118.0832 & $0.040-2.120$ & 0.012 & 0.040 & 0.9848 & 5.6 & 16.4 \\
\hline Glu & $\mathrm{C}_{5} \mathrm{H}_{9} \mathrm{NO}_{4}$ & 7.98 & 148.0610 & 148.0655 & $0.047-2.469$ & 0.014 & 0.047 & 0.9964 & 4.7 & 7.0 \\
\hline GABA & $\mathrm{C}_{4} \mathrm{H}_{9} \mathrm{NO}_{2}$ & 8.21 & 104.0712 & 104.0708 & $0.053-3.440$ & 0.016 & 0.053 & 0.9904 & 7.2 & 16.7 \\
\hline Asp & $\mathrm{C}_{4} \mathrm{H}_{7} \mathrm{NO}_{4}$ & 8.29 & 134.0453 & 134.0433 & $0.106-2.743$ & 0.032 & 0.106 & 0.9965 & 5.2 & 12.6 \\
\hline Ala & $\mathrm{C}_{3} \mathrm{H}_{7} \mathrm{NO}_{2}$ & 8.49 & 90.0555 & 90.0557 & $0.153-2.787$ & 0.046 & 0.153 & 0.9948 & 10.4 & 19.7 \\
\hline Thr & $\mathrm{C}_{4} \mathrm{H}_{9} \mathrm{NO}_{3}$ & 8.51 & 120.0661 & 120.0656 & $0.323-5.837$ & 0.097 & 0.323 & 0.9883 & 6.3 & 14.9 \\
\hline Ser & $\mathrm{C}_{3} \mathrm{H}_{7} \mathrm{NO}_{3}$ & 8.73 & 106.0504 & 106.0553 & $0.344-6.789$ & 0.103 & 0.344 & 0.9957 & 9.1 & 15.0 \\
\hline Gly & $\mathrm{C}_{2} \mathrm{H}_{5} \mathrm{NO}_{2}$ & 8.86 & 76.0399 & 76.0491 & $0.587-6.661$ & 0.176 & 0.587 & 0.9858 & 12.3 & 11.2 \\
\hline Pro & $\mathrm{C}_{5} \mathrm{H}_{9} \mathrm{NO}_{2}$ & 8.97 & 116.0706 & 116.0729 & $0.079-6.377$ & 0.024 & 0.079 & 0.9991 & 6.6 & 18.1 \\
\hline Sar & $\mathrm{C}_{3} \mathrm{H}_{7} \mathrm{NO}_{2}$ & 9.08 & 90.0555 & 90.0589 & $0.366-8.018$ & 0.110 & 0.366 & 0.9819 & 8.6 & 17.9 \\
\hline Asn & $\mathrm{C}_{4} \mathrm{H}_{8} \mathrm{~N}_{2} \mathrm{O}_{3}$ & 9.19 & 133.0613 & 133.0625 & $0.261-1.903$ & 0.078 & 0.261 & 0.9988 & 8.2 & 17.4 \\
\hline Gln & $\mathrm{C}_{5} \mathrm{H}_{10} \mathrm{~N}_{2} \mathrm{O}_{3}$ & 9.25 & 147.0764 & 147.0767 & $0.143-4.858$ & 0.043 & 0.143 & 0.9950 & 6.4 & 20.4 \\
\hline Bet & $\mathrm{C}_{5} \mathrm{H}_{10} \mathrm{NO}_{2}$ & 10.35 & 118.0868 & 118.0844 & $0.115-2.149$ & 0.035 & 0.115 & 0.9967 & 8.8 & 16.5 \\
\hline Arg & $\mathrm{C}_{6} \mathrm{H}_{14} \mathrm{~N}_{4} \mathrm{O}_{2}$ & 11.78 & 175.1190 & 175.1162 & $0.059-2.000$ & 0.018 & 0.059 & 0.9784 & 10.3 & 11.1 \\
\hline His & $\mathrm{C}_{6} \mathrm{H}_{9} \mathrm{~N}_{3} \mathrm{O}_{2}$ & 10.95 & 156.0773 & 156.0762 & $2.276-6.487$ & 0.683 & 2.276 & 0.9771 & 7.1 & 8.7 \\
\hline Lys & $\mathrm{C}_{6} \mathrm{H}_{14} \mathrm{~N}_{2} \mathrm{O}_{2}$ & 12.21 & 147.1128 & 147.1135 & $0.473-2.371$ & 0.142 & 0.473 & 0.9110 & 16.2 & 19.1 \\
\hline
\end{tabular}

LOD: limits of detection; LOQ: limits of quantification; $\mathrm{R}^{2}$ : coefficients of determination; RSD: relative standard deviation; Trp: L-tryptophan; Phe: L-phenylalanine; Tyr: L-tyrosine; Leu: L-leucine; Ile: L-isoleucine; Met: L-methionine; Val: L-valine; Glu: L-glutamic acid; GABA: $\gamma$-aminobutyric acid; Asp: L-aspartic acid; Ala: L-alanine; Thr: L-threonine; Ser: L-serine; Gly: L-glycine; Pro: L-proline; Sar: L-sarcosine; Asn: L-asparagine; Gln: L-glutamine; Bet: L-betaine; Arg: L-arginine; His: L-histidine; Lys: L-lysine. 


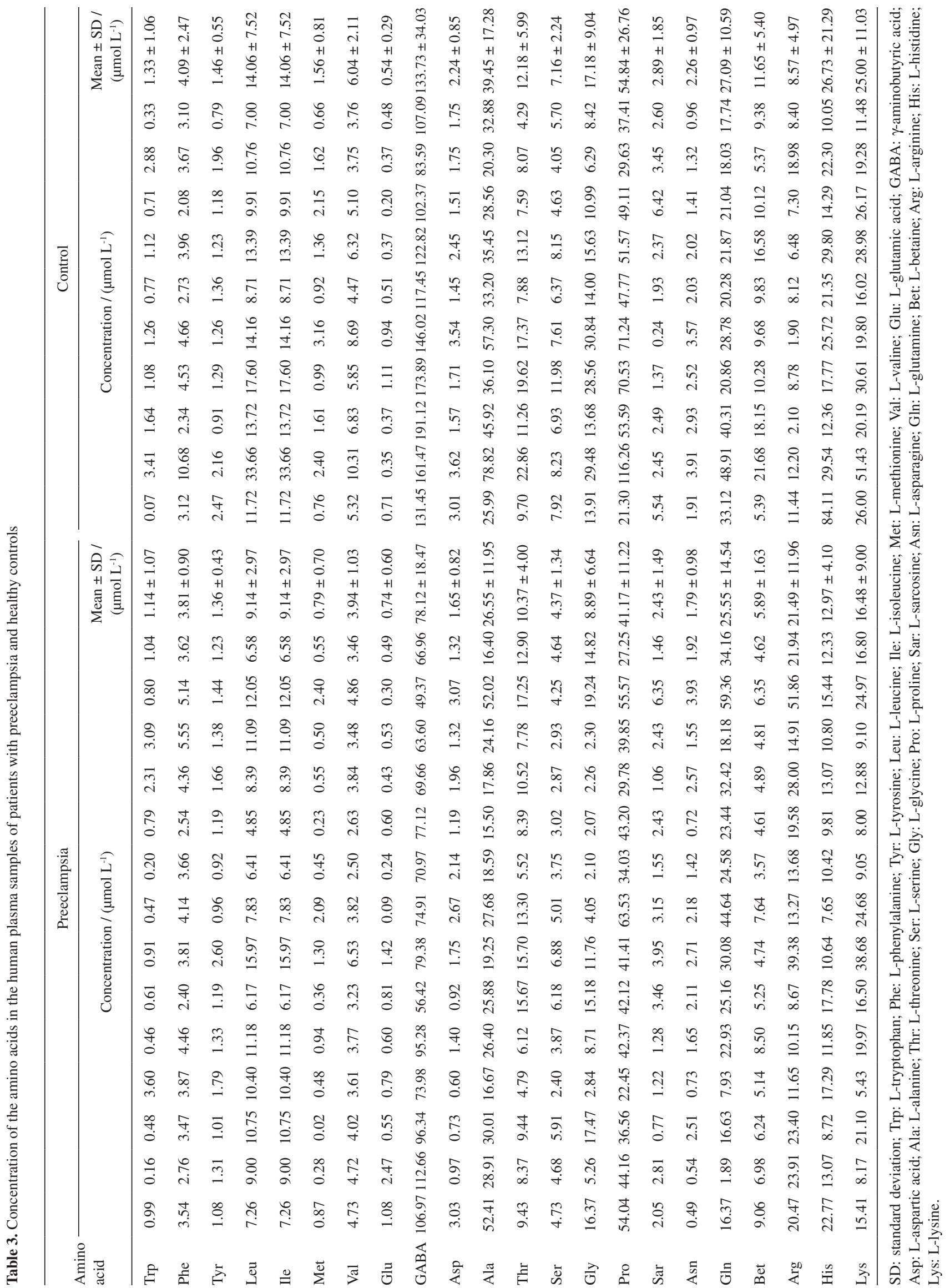




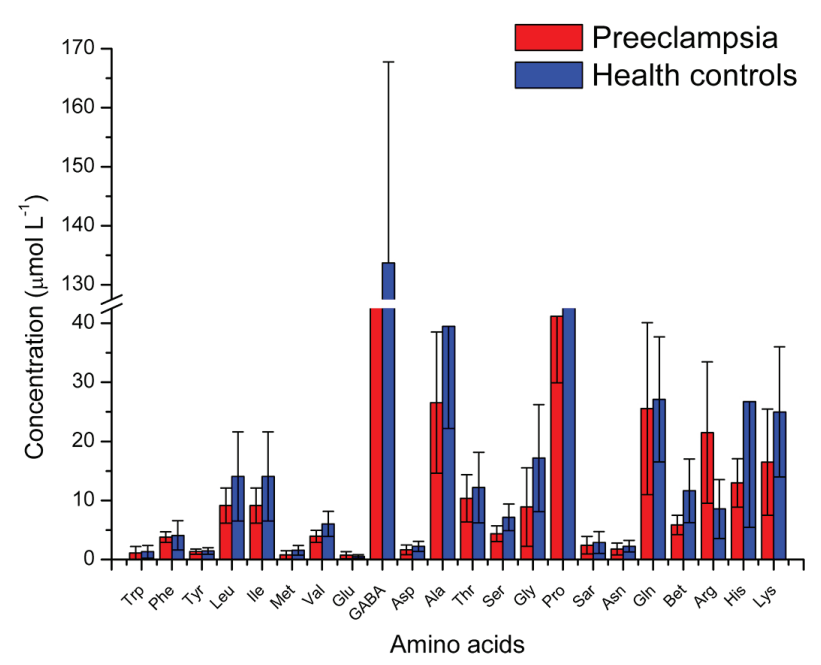

Figure 3. Mean concentrations of L-amino acids determinated in plasma samples of preeclampsia $(n=14)$ patients and healthy controls $(n=10)$.

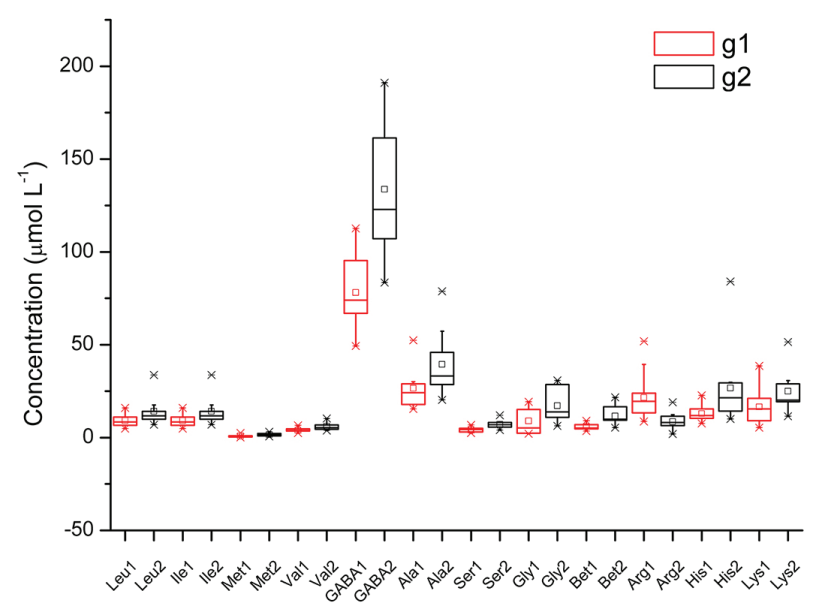

Figure 4. Box plot of the amino acids discriminated by Tukey test in plasma of preeclampsia patients and healthy controls.

the 22 amino acids studied showed significant changes when compared to the amino acids levels analyzed in the control samples of healthy patients. These results revealed that the levels of GABA, Arg, Ser, Leu, Ile, Met, Val, Ala, Gly, Bet, His and Lys were significantly lower in the group of preeclampsia compared to the control group of healthy patients.

\section{Conclusions}

An LC-HRMS optimized method to analyze twenty-two underivatizated L-amino acids was developed. This method showed good linearity, repeatability, reproducibility, and low limits of detection and quantification. It was successfully applied to the determination of L-amino acids in plasma samples of patients with preeclampsia and healthy controls. The amino acids levels of GABA,
Arg, Ser, Leu, Ile, Met, Val, Ala, Gly, Bet, His and Lys presented significant differences between the samples of patients with preeclampsia and healthy controls. Therefore this study offers a tool to improve the understanding of preeclampsia.

\section{Acknowledgments}

Funding for this study was provided by the Conselho Nacional de Desenvolvimento Científico e Tecnológico (CNPq), Fundo Nacional de Saúde (FNS) and the Coordenação de Aperfeiçoamento de Pessoal de Nível Superior, Brazil (CAPES).

\section{References}

1. Xing, Y.; Li, X.; Guo, X.; Cui, Y.; Anal. Bioanal. Chem. 2016, 408, 141.

2. Xu, Y.; Zheng, X.; Qiu, Y.; Jia, W.; Wang, J.; Yin, S.; J. Proteome Res. 2015, 14, 3315.

3. Sugimoto, H.; Kakehi, M.; Jinno, F.; Anal. Bioanal. Chem. 2015, 407, 7889.

4. Chen, Y. C.; Chang, P. L.; Analyst 2015, 140, 847.

5. Mousavi, F.; Bojko, B.; Pawliszyn, J.; Anal. Chim. Acta 2015, $892,95$.

6. Cheng, F.; Wang, Z. W.; Huang, Y. P.; Duan, Y. X.; Wang, X. D.; Clin. Chim. Acta 2015, 447, 23.

7. Qi, W.; Guan, Q.; Sun, T.; Cao, Y.; Zhang, L.; Anal. Chim. Acta 2015, 870, 75 .

8. Mochizuki, T.; Takayama, T.; Todoroki, K.; Inoue, K.; Min, J. Z.; Toyo'oka, T.; Anal. Chim. Acta 2015, 875, 73.

9. Delgado-Povedano, M. M.; Calderon-Santiago, M.; PriegoCapote, F.; de Castro, M. D. L.; Anal. Chim. Acta 2016, 905, 115.

10. Innis, S. M.; Hasman, D.; J. Nutr. 2006, 136, 2226.

11. Suzuki, M.; Furuhashi, M.; Sesoko, S.; Kosuge, K.; Maeda, T.; Todoroki, K.; Inoue, K.; Min, J. Z.; Toyo'oka, T.; Anal. Chim. Acta 2016, 911, 92.

12. Gu, Y.; Chen, T. X.; Fu, S. Z.; Sun, X.; Wang, L. Y.; Wang, J.; Lu, Y. F.; Ding, S. M.; Ruan, G. D.; Tend, L. S.; Wang, M.; J. Transl. Med. 2015, 13, 35.

13. Lin, P. P.; Lee, H. L.; Cheng, H. I.; Chen, C. Y.; Tsai, M. H.; Liu, H. J.; Anal. Bioanal. Chem. 2014, 406, 4287.

14. Ciolacu, F. C. L.; Ardelean, A.; Mandrutiu, I.; Belengeanu, A. D.; Bechet, D.; Mihali, C. V.; Pretescu, C. M.; Benga, G.; Acta Endocrinol. (Bucharest, Rom.) 2015, 11, 431.

15. Nielsen, J.; J. Bacteriol. 2003, 185, 7031.

16. Chen, X. W.; Gao, D.; Liu, F.; Gao, X.; Wang, S. J.; Zhao, Y. F.; Liu, H. X.; Jiang, Y. Y.; Anal. Chim. Acta 2014, 836, 61.

17. Friesen, R. W.; Novak, E. M.; Hasman, D.; Innis, S.; J. Nutr. 2007, 137, 2641. 
18. Nemkov, T.; D’Alessandro, A.; Hansen, K. C.; Amino Acids 2015, 47, 2345.

19. Delgado-Povedano, M. M.; Calderon-Santiago, M.; PriegoCapote, F.; de Castro, M. D. L.; Talanta 2016, 146, 310.

20. Paiva, M. J. N.; Menezes, H. C.; Christo, P. P.; Resende, R. R.; Cardeal, Z. L.; J. Chromatogr. B: Biomed. Sci. Appl. 2013, 931, 97.

21. Cocuron, J.-C.; Tsogtbaatar, E.; Alonso, A. P.; J. Chromatogr. A 2017, 1490, 148.

22. Alpert, A. J.; J. Chromatogr. A 1990, 499, 177.

23. Buszewski, B.; Noga, S.; Anal. Chim. Acta 2012, 402, 231.

24. Periat, A.; Kohler, I.; Bugey, A.; Bieri, S.; Versace, F.; Staub, C.; Guillarme, D.; J. Chromatogr. A 2014, 1356, 211.

25. Eurachem; Guide to Quality in Analytical Chemistry an AID to Accreditation; CITAC/Eurachem, 2002. Available at https://www.eurachem.org/images/stories/Guides/pdf/ CITAC_EURACHEM_GUIDE_2nd_ed_EN.pdf, accessed in April 2019.

26. Origin 8.0; OriginLab Corporation, Northampton, MA, USA, 2009.

27. Austdal, M.; Thomsen, L. C. V.; Tangerås, L. H.; Skei, B.; Mathew, S.; Bjorge, L.; Austgulen, R.; Bathen, T. F.; Iversen, A.-C.; Placenta 2015, 36, 1455.
28. Kelly, R. S.; Croteau-Chonka, D. C.; Dahlin, A.; Mirzakhani, H.; Wu, A. C.; Wan, E. S.; McGeachie, M. J.; Qiu, W.; Sordillo, J. E.; Al-Garawi, A.; Gray, K. J.; McElrath, T. F.; Carey, V. J.; Clish, C. B.; Litonjua, A. A.; Weiss, S. T.; Lasky-Su, J. A.; Metabolomics 2017, 13, DOI 10.1007/s11306-016-1149-8.

29. Austdal, M.; Tangeras, L. H.; Skråstad, R. B.; Salvesen, K. Å.; Austgulen, R.; Iversen, A.-C.; Bathen, T. F.; Int. J. Mol. Sci. 2015, 16, 21520.

30. Bahado-Singh, R. O.; Syngelaki, A.; Akolekar, R.; Mandal, R.; Bjondahl, T. C.; Han, B.; Nicolaides, K. H.; Am. J. Obstet. Gynecol. 2015, 213, 530e1.

31. Kenny, L. C.; Broadhurst, D. I.; Dunn, W.; Brown, M.; North, R. A.; Mccowan, L.; Baker, P. N.; Hypertension 2010, 56, 741.

32. Kuc, S.; Koster, M. P.; Pennings, J. L.; Hankemeier, T.; Berger, R.; Harms, A. C.; Vreeken, R. J.; PLoS One 2014, 9, e98540.

33. Schott, S.; Hahn, J.; Kurbacher, C.; Moka, D.; Int. J. Biomed. Sci. 2012, 8, 258.

34. Austdal, M.; Skrastad, R. B.; Gundersen, A. S.; Austgulen, R.; Iversen, A. C.; Bathen, T. F.; PLoS One 2014, 9, e91923.

Submitted: January 22, 2019

Published online: May 14, 2019 